\title{
Effect of Chitosan Coating on the Structure and Properties of Highly-Porous Bioceramic Scaffolds for Bone Tissue Engineering
}

\author{
O. Eu. Sych ${ }^{1}$, A. P. Iatsenko ${ }^{2}$, T. V. Tomila ${ }^{1}$, O. I. Bykov ${ }^{1}$, A. Chodara ${ }^{3}$, \\ R. Mukhovskyi ${ }^{3}$, J. Mizeracki ${ }^{3}$, S. Gierlotka ${ }^{3}$, W. Łojkowski ${ }^{3}$, and \\ Y. I. Yevych ${ }^{1}$
}

${ }^{1}$ Frantsevich Institute for Problems of Materials Science, N.A.S. of Ukraine, 3, Krzhyzhanovsky Str.,

UA-03142 Kyiv, Ukraine

${ }^{2}$ National Technical University of Ukraine

'Igor Sikorsky Kyiv Polytechnic Institute',

37, Peremogy Ave.,

UA-03056 Kyiv, Ukraine

${ }^{3}$ Institute of High Pressure Physics of the Polish Academy of Sciences, 29/37, Sokolowska Str.,

01-142 Warsaw, Poland

Highly-porous bioceramic scaffolds based on biogenic hydroxyapatite with addition of 40 wt. $\%$ of glass (wt.\%: $45.7 \mathrm{SiO}_{2}, 28.2 \mathrm{~B}_{2} \mathrm{O}_{3}, 26.1 \mathrm{Na}_{2} \mathrm{O}$ ) were prepared by foam replication method at $700^{\circ} \mathrm{C}$ followed by coating of chitosan dissolved in $1 \%$ acetic acid solution and drying at $50^{\circ} \mathrm{C}$. Bioceramic samples were studied by XRD, IR spectroscopy and SEM. Phase composition, morphology, skeleton density, porosity, compression strength and in vitro tests were evaluated. The results show that, during sintering, the biogenic hydroxyapatite in bioceramic composition is stable and keeps hydroxyapatite phase without secondary phase formation. Chitosan coating shows twofold increase in the compression strength in comparison with pure bioceramics. Moreover, chitosan coating significantly influences on the structure of highly-porous bioceramic scaffolds and dissolution rate in saline. Thus, balanced porosity and compression strength and dissolution rate make the prepared materials promising for bone marrow stromal cell loading, drug delivery and bone tissue engineering application.

Високопористі біокерамічні підкладинки на основі біогенного гідроксиапатиту з додаванням 40 мас.\% скла (мас.\%: 45,7 $\mathrm{SiO}_{2}, 28,2 \mathrm{~B}_{2} \mathrm{O}_{3}, 26,1$ $\mathrm{Na}_{2} \mathrm{O}$ ) було одержано методом дублювання структури полімерної матриці при $700^{\circ} \mathrm{C}$ із наступним нанесенням покриття хітозану, розчиненого в $1 \%$-розчині оцтової кислоти, та сушкою при $50^{\circ} \mathrm{C}$. Зразки біоке- 
раміки були досліджені методами РФА, ІЧ-спектроскопії та СЕМ. Оцінювали фазовий склад, морфологію, істинну густину, пористість, міцність на стиск і виконували досліди in vitro. Результати показали, що при спіканні біогенний гідроксиапатит у біокерамічній композиції стабільний і зберігає фазу гідроксиапатиту без утворення вторинних фаз. Хітозанове покриття показало збільшення міцности на стиск у 2 рази у порівнянні з чистою біокерамікою. Крім того, хітозанове покриття істотно впливає на структуру високопористих біокерамічних підкладинок і швидкість розчинення їх у фізіологічному розчині. Таким чином, баланс пористости, міцности на стиск і швидкости розчинення робить одержані матеріяли перспективними носіями стовбурових стромальних клітин кісткового мозку, для доставки лікарських засобів і застосування в інженерії кісткової тканини.

Высокопористые биокерамические подложки на основе биогенного гидроксиапатита с добавлением 40 масс.\% стекла (масс. $\%: 45,7 \mathrm{SiO}_{2}, 28,2$ $\mathrm{B}_{2} \mathrm{O}_{3}, 26,1 \mathrm{Na}_{2} \mathrm{O}$ ) были получены методом дублирования структуры полимерной матрицы при $700^{\circ} \mathrm{C}$ с последующим нанесением покрытия хитозана, растворенного в $1 \%$-растворе уксусной кислоты, и сушкой при $50^{\circ} \mathrm{C}$. Образцы биокерамики были исследованы методами РФА, ИК-спектроскопии и СЭМ. Были оценены фазовый состав, морфология, истинная плотность, пористость, прочность на сжатие и проведены тесты in vitro. Результаты показали, что при спекании биогенный гидроксиапатит в биокерамической композиции стабилен и сохраняет фазу гидроксиапатита без образования вторичных фаз. Хитозановое покрытие показало увеличение прочности на сжатие в 2 раза по сравнению с чистой биокерамикой. Кроме того, хитозановое покрытие существенно влияет на структуру высокопористых биокерамических подложек и скорость их растворения в физиологическом растворе. Таким образом, баланс пористости, прочности на сжатие и скорости растворения делает полученные материалы перспективными в качестве носителей стволовых стромальных клеток костного мозга, для доставки лекарств и применения в инженерии костной ткани.

Key words: hydroxyapatite, chitosan, highly-porous material, foam replication method, biomaterial.

Ключові слова: гідроксиапатит, хітозан, високопоруватий матеріял, метода дублювання структури полімерної матриці, біоматеріял.

Ключевые слова: гидроксиапатит, хитозан, высокопористый материал, метод дублирования структуры полимерной матрицы, биоматериал.

(Received 3 December, 2019; in revised form, 5 February, 2020)

\section{INTRODUCTION}

The organic/inorganic composites for the treatment of bone diseases have been of great interest due to their ability to combine the ad- 
vantages of polymeric matrix with those of inorganic components and their better properties compared with the pure components.

Bioceramics based on the synthetic and biogenic (natural) hydroxyapatite (HA), $\mathrm{Ca}_{10}\left(\mathrm{PO}_{4}\right)_{6}(\mathrm{OH})_{2}$, is most widely used as scaffolds due to significant chemical and physical resemblance of HA to the mineral constituents of human bones and teeth, its excellent biocompatibility, bioactivity and osteoconductive properties [1]. The ability to regenerate human tissue depends on the porosity of scaffolds structure that should be interconnected with proper pore size 100-600 $\mu \mathrm{m}$ and more $70 \%$ to enable cell infiltration, tissue ingrowth and vascularization, and nutrient delivery to the centre of the regenerated tissue [2]. In our previous works, it was shown that highlyporous glass ceramics based on biogenic hydroxyapatite (BHA) prepared by foam replication method [3-5] increase the cloning efficiency and stimulate proliferation and differentiation of marrow stromal cells [6].

At the same time, chitosan is a unique polysaccharide-based biopolymer (deacetylated derivative of chitin) that shares a number of chemical and structural similarities with collagen. The high content of reactive functional groups along chitosan molecule provides possibilities of its structure modification. Chitosan has good biocompatible, non-toxic, biodegradable and inherent wound healing characteristics, as well as bioactivity that includes haemostatic, fungistatic, antibacterial, antitumoral, anticholesteremic and the most important osteoconductive properties, supports the growth, function and cellular activity of osteoblasts. It is a flexible polymer and does not meet the mechanical properties of natural bones, but modification of bioceramic scaffolds with controlled morphology by chitosan is promising for medical use [7-11].

The present work is aimed on studying the effect of chitosan coating on the structure and properties of highly-porous bioceramics.

\section{METHODS AND MATERIALS}

In the present work, the following starting materials were used for samples preparation:

i) BHA obtained by calcination of cattle bones at $900^{\circ} \mathrm{C}$ followed by grinding to particle size $\leq 160 \mu \mathrm{m}$. In our previous studies [12, 13], the BHA morphology has been investigated by the method of transmission electron microscopy, and it was established that the BHA powder was composed of irregularly formed agglomerates from round $100-500 \mathrm{~nm}$ particles.

ii) sodium borosilicate glass (wt.\%: 45, $7 \mathrm{SiO}_{2}, 28,2 \mathrm{~B}_{2} \mathrm{O}_{3}$, $26,1 \mathrm{Na}_{2} \mathrm{O}$ ) was produced by melting a mixture of the glass-forming components at $1200^{\circ} \mathrm{C}$ followed by grinding to particle size $\leq 160$ 
$\mu \mathrm{m}$

iii) foamed polyurethane matrix (ST 3542, Interfoam) with a permeable porous structure (porosity $95 \%$ );

iiii) commercial Chitosan-50 powder $\left(\left(\mathrm{C}_{6} \mathrm{H}_{11} \mathrm{NO}_{4}\right)_{n}, M=500,000\right.$, Wako Pure Chemical Industries Ltd.).

Highly-porous bioceramic samples (BHA $/ \mathrm{B}_{2} \mathrm{O}_{3}$ glass) were made using foam replication method described in [3-4], which includes the following procedures. Ceramic slurry was prepared based on BHA and sodium borosilicate glass $(60 / 40$ ratio, wt. $\%)$ using $0.1 \%$ gelatine water solution at ball mill. Prepared slurry was put on foam template followed by drying at $80^{\circ} \mathrm{C}$ for $4 \mathrm{~h}$ and sintering in a muffle furnace (SNOL-1,7.3.1,2/1200) at $700^{\circ} \mathrm{C}$ (heating rate $3^{\circ} \mathrm{C} / \mathrm{min}$, maintaining $1 \mathrm{~h}$ ). Moreover, prepared bioceramic samples were coated (impregnated) with $1 \%$ chitosan solution in $1 \%$ acetic acid solution and dried at $50^{\circ} \mathrm{C}$ to constant weight.

The phase composition of starting powders and prepared highlyporous samples was controlled by x-ray diffraction (XRD) analysis using X'Pert PRO (PANalytical) diffractometer equipped with a copper anode $(\lambda=1.54 \AA)$ and infrared (IR) spectroscopy using a Fourier-spectrometer FCM 1202 (Infraspectr) in the frequency range $4000-400 \mathrm{~cm}^{-1}$ using $\mathrm{KBr}$ pellets.

The structure of the samples was examined using scanning electron microscopy (SEM) by Zeiss Ultra Plus (Carl Zeiss Meditec AG, Germany) microscope.

The total porosity of the samples was calculated using the skeleton density values measured by helium pycnometer AccuPyc II 1340 (Micromeritics) at room temperature according to ISO 12154:2014 and apparent density calculated based on geometric dimensions and mass of the samples. Open porosity measurement was performed in ethanol using the Archimedes principle.

Compression strength was determined with the aid of a multipurpose machine Ceram Test System (Ukraine) with loading rate 0.02 $\mathrm{mm} / \mathrm{min}$.

In vitro experiments of highly-porous samples, in particular dissolution rate in saline $(0.9 \% \mathrm{NaCl}$ water solution), was evaluated at a solid/liquid ratio of 1:50 after 2 days soaking in a thermostat at $36.5 \pm 0.5^{\circ} \mathrm{C}$ followed by determination of mass loss on an analytic balance 'OHAUS Pioneer PA214C' (OHAUS Corporation, China).

\section{RESULTS AND DISCUSSION}

Figure 1 demonstrates XRD patterns of initial chitosan and BHA powders as well as highly-porous bioceramics with and without chitosan coating. The pure chitosan powder showed the characteristic peaks of chitosan at $20.2^{\circ}$ and $39.9^{\circ}$ (JCPDS Card No. 39-1894). 


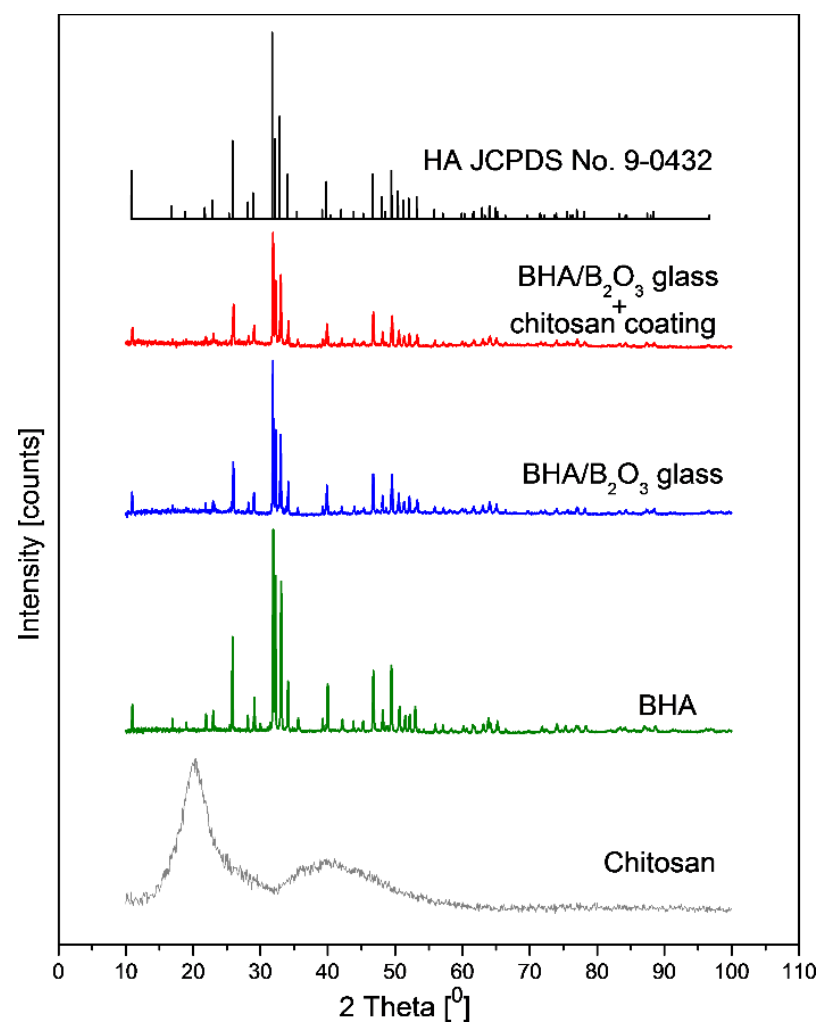

Fig. 1. XRD patterns of starting chitosan, BHA and bioceramics with and without chitosan coating.

BHA presented by the crystalline $\mathrm{HA}$ phase $\mathrm{Ca}_{5}\left(\mathrm{PO}_{4}\right)_{3}(\mathrm{OH})$, corresponding to the standard data in JCPDS Card No. 09-0432. Ceramic samples preserves HA phase composition, which confirms the literature information and our previous investigations of BHA thermal stability [14-17]. XRD patterns of highly-porous bioceramics with and without chitosan coating have peaks with lower intensity in comparison to the initial BHA that connected with the presence of amorphous phase of glass and organic chitosan in the samples. These results are confirmed by IR spectroscopy data.

Figure 2 shows IR spectra of initial BHA and chitosan and $\mathrm{BHA} / \mathrm{B}_{2} \mathrm{O}_{3}$ glass samples with and without chitosan coating. The spectrum of initial chitosan showed characteristic peaks of methylene $\left(\mathrm{CH}_{2}\right)$ at 1420,2875 and $2930 \mathrm{~cm}^{-1}$, amide $\mathrm{I}(\mathrm{C}=\mathrm{O})$ at 1655,1635 and $1463 \mathrm{~cm}^{-1}$, amide II $\left(\mathrm{N}-\mathrm{H}\right.$ deformation in $\left.\mathrm{NH}_{2}\right)$ at 1602 and $1560 \mathrm{~cm}^{-1}$ and amide III $(\mathrm{C}-\mathrm{N})$ band at $1321 \mathrm{~cm}^{-1}$ [18-21]. The $\mathrm{CH}_{3}$ symmetrical deformation was confirmed by the presence of band around $1380 \mathrm{~cm}^{-1}$. The adsorption band at $1155 \mathrm{~cm}^{-1}$ can be at- 


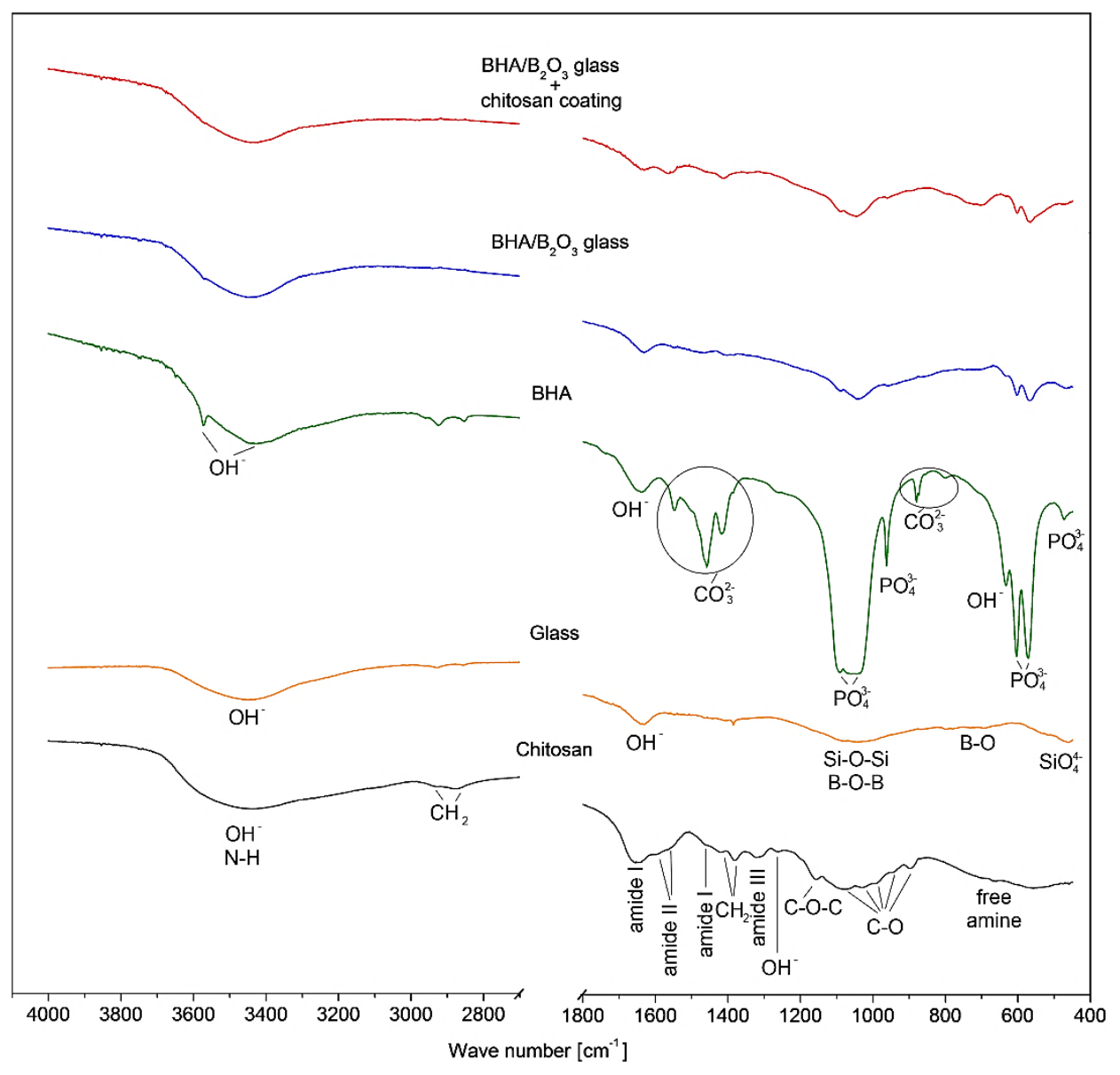

Fig. 2. IR spectra of starting chitosan, glass, BHA and bioceramics without and with chitosan coating.

tributed to asymmetric stretching of the $\mathrm{C}-\mathrm{O}-\mathrm{C}$ bridge. The bands at 1075,1030 and $898 \mathrm{~cm}^{-1}$ correspond to $\mathrm{C}-\mathrm{O}$ stretching and band at $670 \mathrm{~cm}^{-1}$ connected with free amine [20, 22]. The bands at around 1260 and $3435 \mathrm{~cm}^{-1}$ correspond to the stretching vibration of hydroxyl groups overlapped with $\mathrm{N}-\mathrm{H}$ stretching bands. All of these identified bands are characteristic of chitosan [23].

The spectrum of sodium borosilicate glass indicates the presence of asymmetric valence $\mathrm{B}-\mathrm{O}$ vibrations in the trigonal coordination of boron $\left(\mathrm{BO}_{3}^{-}\right)$in the range $1500-1400 \mathrm{~cm}^{-1}$ and deformation vibrations $\mathrm{B}-\mathrm{O}-\mathrm{B}$ at $\cong 700 \mathrm{~cm}^{-1}$. The absorption bands in the region $\cong 1150-950$ $\mathrm{cm}^{-1}$ associated with the $\mathrm{Si}-\mathrm{O}-\mathrm{Si}$ and $\mathrm{B}-\mathrm{O}-\mathrm{B}$ valence vibrations and band at $\cong 470 \mathrm{~cm}^{-1}$ corresponds to the deformation $\mathrm{Si}-\mathrm{O}-\mathrm{Si}$ vibrations of $\mathrm{SiO}_{4}{ }^{4-}$. Moreover, the spectrum contains bands the $\mathrm{OH}^{-}$group at 
$\cong 3440 \mathrm{~cm}^{-1}$ and $\cong 1635 \mathrm{~cm}^{-1}$, which connected with valence and deformation vibrations, respectively. The IR spectrum of BHA has characteristic bands of crystalline hydroxyapatite related to the vibrations of $\mathrm{PO}_{4}{ }^{3-}\left(1090,1050,960,604,570\right.$, and $\left.470 \mathrm{~cm}^{-1}\right)$ and $\mathrm{OH}^{-}$ $\left(3570,3440,1630,630 \mathrm{~cm}^{-1}\right)$ groups. In addition, the spectrum reflexes the vibrations of the carbonate group at $\cong 1550,1457,1415$, 880 , and $800 \mathrm{~cm}^{-1}$ and $\mathrm{CO}_{3}{ }^{2-}$-ions are located in both the A-site (replacing $\mathrm{OH}^{-}$groups) and the B-site (replacing $\mathrm{PO}_{4}{ }^{3-}$ groups) [24-26].

For $\mathrm{BHA} / \mathrm{B}_{2} \mathrm{O}_{3}$ glass bioceramics with and without chitosan coating we can see overlapping IR absorption bands of BHA, sodium borosilicate glass and chitosan and broadening and decreasing in the intensity of all main line that attributed to HA that connected with the presence of amorphous glass phase and organic chitosan. IR spectroscopy did not fix formation of new bands.

Prepared bioceramic samples have an open interacted pore structure with pore size from 10 to $700 \mu \mathrm{m}$ characterized by the presence of arc-like separation walls, which prevent from formation of completely closed cells and disconnected volumes in the material (Fig. 3). Moreover, 'closed bubbles' that forms due to the liquid-phase sintering and low viscosity of glass at sintering temperature and vitrified particles are presented. After chitosan coating the surface of composites have 'film' and at high magnification the chitosan particles like flakes have been observed. The total and open porosity for $\mathrm{BHA} / \mathrm{B}_{2} \mathrm{O}_{3}$ glass samples is equal to 93.7 and $71.5 \%$, respectively. After chitosan coating, the total and open porosity was slowly decreased to 93.2 and $69.0 \%$, respectively.

Figure 4 lists the results of skeleton density of starting materials and bioceramics without and with chitosan coating. For $\mathrm{BHA} / \mathrm{B}_{2} \mathrm{O}_{3}$ glass samples the density values is lower than the same one for BHA and glass that could be connected with the features of liquid phase sintering of materials and formation of $22 \%$ of closed porosity. Chitosan coating practically does not affect the density due to low density and content.

It was established the significant influence of chitosan coating on dissolution rate and structure of bioceramics after interaction with saline. The dissolution rate of $\mathrm{BHA} / \mathrm{B}_{2} \mathrm{O}_{3}$ glass samples without and with chitosan coating was found to be 3.3 and 5.5 wt.\%/day. According to SEM results, the structure of the samples significant changes after experiments in vitro (Fig. 3). After interaction with saline, the surface of $\mathrm{BHA} / \mathrm{B}_{2} \mathrm{O}_{3}$ glass composites leaches and particle of BHA have been observed (at high magnification). For bioceramic samples, we can see decreasing the particle size on the surface of the material due to its partial dissolution.

Moreover, it was shown that chitosan coating allows 2 times increasing the compression strength of bioceramic samples from 0.25 


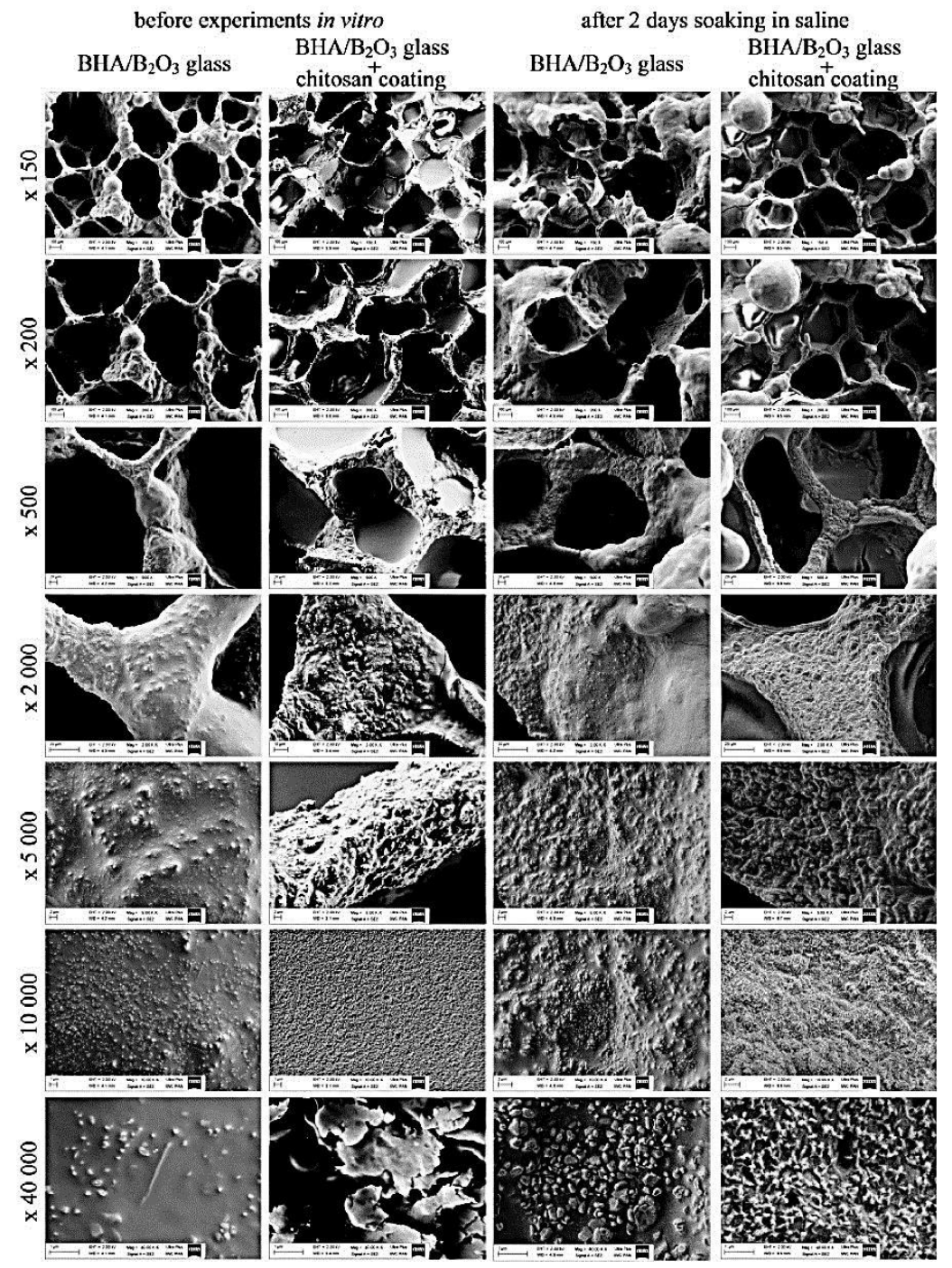

Fig. 3. Structure of bioceramics without and with chitosan coating before and after experiments in vitro.

to $0.55 \mathrm{MPa}$. It should be noted that the obtained strength of the material is sufficient to perform the required manipulations during implantation with no failure of the samples.

\section{CONCLUSIONS}

The prepared highly-porous bioceramic scaffolds based on biogenic 


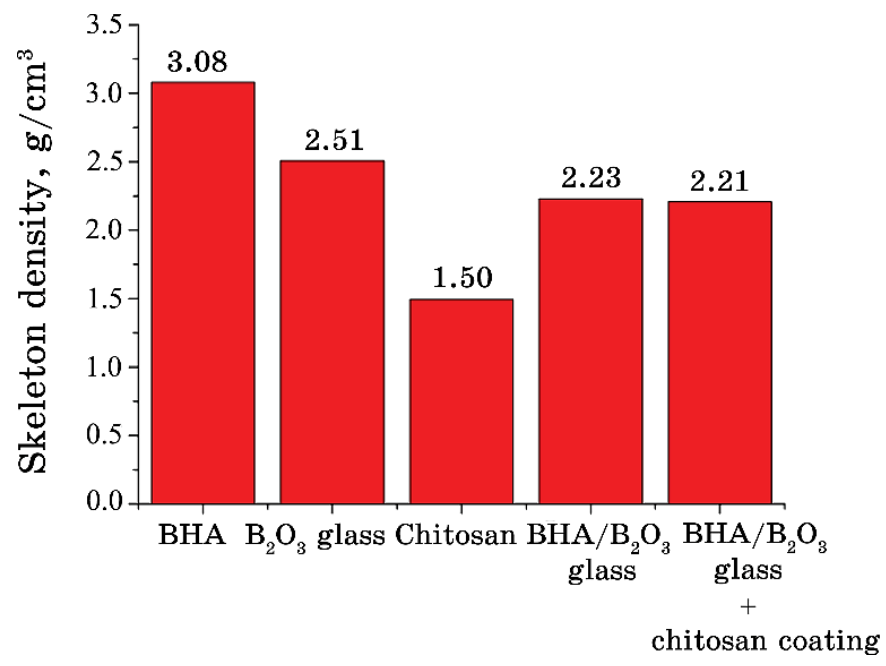

Fig. 4. Skeleton density of starting chitosan, glass, BHA and bioceramics without and with chitosan coating.

hydroxyapatite and sodium borosilicate glass with chitosan coating were prepared by foam replication method and evaluated for their composition, structure, mechanical properties and behaviour in vitro (in saline). The XRD and IR spectroscopy results showed no phase transformation of hydroxyapatite in bioceramics scaffolds. It was observed that there was significant increase in the compression strength of the bioceramic samples after chitosan coating from 0.25 up to $0.55 \mathrm{MPa}$ as compared to the samples without coating. From SEM and in vitro investigations, it can be concluded that chitosan coating significant influences on the structure of scaffolds and dissolution rate in saline. These observations indicate the potency of prepared scaffolds for the use in biomedical applications.

\section{ACKNOWLEDGMENTS}

The publication contains the results of studies conducted by Grant for monthly visits of Ukrainian scientists to Poland according to the Protocol to the Agreement on Scientific Cooperation between the National Academy of Sciences of Ukraine and Polish Academy of Sciences.

\section{REFERENCES}

1. L. Roseti, V. Parisi, M. Petretta, C. Cavallo, G. Desando, I. Bartolotti, and B. Grigolo, Mater. Sci. Eng. C, 78: 1246 (2017); 
https://doi.org/10.1016/j.msec.2017.05.017.https://s100.copyright.com/ AppDispatch-

Servlet?publisherName $=$ ELS\&contentID $=$ S0928493117317228\&order BeanReset=true.

2. $\quad$ L. C. Gerhardt and A. R. Boccaccini, Materials, 3: 3867 (2010); DOI: $10.3390 / \mathrm{ma} 3073867$.

3. A. Yatsenko, O. Sych, and T. Tomila, Proc. Appl. Ceram., 9, No. 2: 99 (2015); DOI: 10.2298/PAC1502099I.

4. E. E. Sych, A. P. Yatsenko, T. V. Tomila, A. B. Tovstonog, and Ya. I. Yevych, Powder Metall. Met. Ceram., 55: 319 (2016); https://doi.org/10.1007/s11106-016-9808-x.

5. O. Sych, A. Iatsenko, H. Tovstonoh, T. Tomila, and Ya. Yevych, Funct. Ma ter., 24, No. 1: 46 (2017); doi: 10.15407/fm24.01.046.

6. L. M. Panchenko, O. Ye. Sych, and A. P. Iatsenko, Orthop Traumatol Prosthet., 4: 50 (2014).

7. $\quad$ R. A. A. Muzzare, Carbohydr. Polym., 76: 167 (2009); https://doi.org/10.1016/j.carbpol.2008.11.002.https://s100.copyright.co $\mathrm{m} /$ AppDispatchServlet? publisherName=ELS\&contentID=S014486170 8005183\&orderBeanReset=true.

8. S. Saravanan, R. S. Leena, and N. Selvamurugan, Int. J. Biol. Macromol., 93: 1354 (2016);

https://doi.org/10.1016/j.ijbiomac.2016.01.112.https://s100.copyright.c om/AppDispatchServlet?publisherName=ELS\&contentID=S01418130 16301155\&orderBeanReset $=$ true.

9. Y. B. Rubaiya, K. T. S. Sampath, and D. Mukesh, Mater. Sci. Eng. C, 57: 452 (2015);

https://doi.org/10.1016/j.msec.2015.07.016.https://s100.copyright.com/ AppDispatch-

Servlet? publisherName $=$ ELS\&contentID $=$ S0928493115302010\&order BeanReset $=$ true.

10. M. A. Nazeer, E. Yilgör, and I. Yilgör, Carbohydr. Polym., 175: 38 (2017); https://doi.org/10.1016/j.carbpol.2017.07.054.https://s100.copyright.co $\mathrm{m} /$ AppDispatchServlet?publisherName=ELS\&contentID=S014486171 7308317\&orderBeanReset=true.

11. A. Ressler, J. Rydenas-Rochina, M. Ivanković, H. Ivanković, and G. G. Ferrer, Carbohydr. Polym., 197: 469 (2018);

https://doi.org/10.1016/j.carbpol.2018.06.029.

12. O. Sych, N. Pinchuk, A. Parkhomey, A. Kuda, L. Ivanchenko, V. Skorokhod, O. Vasylkiv, O. Getman, and Y. Sakka, Funct. Mater., 14, No. 4: 430 (2007).

13. O. Sych and N. Pinchuk, Proc. Appl. Ceram., 1, Iss. 1-2: 1 (2007).

14. F. N. Oktar, Ceram. Int., 33: 1309 (2007); doi: $10.1016 /$ j.ceramint.2006.05.022.

15. G. Gergely, F. Wéber, I. Lukács, A. L. Tyth, Z. H. Horváth, J. Mihály, and C. Balázsi, Ceram. Int., 36: 803 (2010); doi:10.1016/j.ceramint.2009.09.020.https://s100.copyright.com/AppDis patch-

Servlet?publisherName $=$ ELS\&contentID $=$ S027288420900354X\&orde rBeanReset $=$ true. 
16. O. Sych, N. Pinchuk, and L. Ivanchenko, Proc. Appl. Ceram., 3, Iss. 3: 157 (2009); doi: 10.2298/PAC0903157S.

17. G. B. Tovstonog, O. E. Sych, and V. V. Skorokhod, Powder Metall. Met. Ceram., 53: 566 (2015); doi: 10.1007/s11106-015-9651-5.

18. P. L. Granja, A. I. N. Silva, João P. Borges, C. C. Barrias, and I. F. Amaral, Key Eng. Mater., 254-256: 573 (2004);

https://doi.org/10.4028/www.scientific.net/KEM.254-256.573.

19. A. Yoshida, T. Miyazaki, E. Ishida, and M. Ashizuka, Mater. Trans., 45, No. 4: 994 (2004).

20. H. K. Varma, Y. Yokogawa, F. F. Espinosa, Y. Kawamoto, K. Nishizawa, F. Nagata, and T. Kameyama, Biomaterials, 20: 879 (1999); doi:10.1016/s0142-9612(98)00243-9.

21. H. H. Abdel-Razik and H. A. Almahy, Int. J. Chem. Sci., 13: 1713 (2015).

22. M. F. Queiroz, K. R. T. Melo, D. A. Sabry, G. L. Sassaki, and H. A. O. Rocha, Mar. Drugs, 13: 141 (2015); https://doi.org/10.3390/md13010141.

23. C. Song, H. Yu, M. Zhang, Y. Yang, and G. Zhang, Int. J. Biol. Macromol., 60: 347 (2013); doi: 10.1016/j.ijbiomac.2013.05.039.

24. M. A. Ouis, A. M. Abdelghany, and H. A. Elbatal, Process. Appl. Ceram., 6, Iss. 3: 141 (2012); doi: 10.2298/PAC12031410.

25. C. Gautam, A. K. Yadav, and A. K. Singh, Int. Sch. Res. Notices, Ceramics: 1 (2012); https://www.hindawi.com/journals/isrn/2012/428497/.

26. O. R. Parkhomei, N. D. Pinchuk, O. E. Sych, T. V. Tomila, H. B. Tovstonoh, V. F. Gorban', Y. I. Yevych, and O. A. Kuda, Powder Metall. Met. Ceram., 55: 172 (2016); https://doi.org/10.1007/s11106-016-9792-1. 